\title{
Effect of Cardamom and Ginger Powder Supplementation on Body Weight Gain and Feed Efficiency in Caged Broilers
}

\author{
Ramkumar Thakur ${ }^{1}$, Neeraj ${ }^{1}$, Ramesh Pandey ${ }^{1}$, \\ Amit Kumar Singh ${ }^{2 *}$ and Abhishek Nagar ${ }^{1}$ \\ ${ }^{1}$ Department of Animal Husbandry \& Dairying, Sam Higginbottom University of Agriculture, \\ Technology and Sciences, Prayagraj, India \\ ${ }^{2}$ ICAR- National Dairy Research Institute, Karnal, India \\ *Corresponding author
}

\section{A B S T R A C T}

Keywords

Cardamom, Ginger, Weight gain, FCR, Caged Broilers

\section{Article Info}

Accepted:

20 July 2020

Available Online:

10 August 2020
Use of antibiotics has been found to have negative effects on broiler health and its production therefore; there is a need for supplementation of herbal ingredients in broiler feed. An experiment was conducted on herbal dietary supplementation of Cardamom and Ginger powder to study its effect on growth performance in caged broilers. A total of 48 Day old broiler chicks of same hatch were procured and randomly divided into four groups with three sub groups comprising of 3 chicks in each to serve as replicates $\mathrm{T}_{0}$ (control) had standard ration as per NRC; $\mathrm{T}_{1}$ ration was supplemented with $0.5 \mathrm{~g}$ Cardamom powder $/ \mathrm{kg}$ feed; $\mathrm{T}_{2}$ ration was supplemented with $0.5 \mathrm{~g}$ Ginger powder $/ \mathrm{kg}$ feed and $\mathrm{T}_{3}$ ration was supplemented with 0.25 Cardamom +0.25 Ginger powder $/ \mathrm{kg}$ feed. The birds were reared in battery type cages under standard management practices from day-old to five weeks of age. The best results for body weight gain $(\mathrm{p}<0.05)$ was seen for the group of caged chicks supplemented with combination of Cardamom and Ginger powder each @ $0.25 \mathrm{~g} / \mathrm{kg}$ feed followed by individually supplementing chicks with Cardamom and Ginger powder than without supplemented group i.e. control group. However, feed efficiency was similar among different groups ( $p>0.05)$. Nevertheless, there was significant effect of weeks of cage rearing in the feed efficiency $(\mathrm{p}<0.05)$. Hence, from this study it can be concluded that supplementation of Cardamom and Ginger powder in combination form may be done to achieve improved body weight gain at finisher stage.

\section{Introduction}

India has the world's second largest emerging economy. Poultry sector is one of the fastest growing sectors in India. It has an immense scope for obtaining handsome amount of money and hence income generation. India has witnessed, average growth rate of $6 \%$ in egg production and $12 \%$ for broiler production per annum. Total poultry population in India has increased by $16.81 \%$ to 851.81 million from 729.21 million in numbers (BAHS, 2019). India stands on $3^{\text {rd }}$ position in egg production; however, it is still growing in terms of poultry meat production and stands on $6^{\text {th }}$ position in the world in 
terms of broiler production. Rise in consumer demand for poultry is responsible for driving the recent growth of the Indian poultry sector. Poultry meat especially chicken meat is covering meat market over the world. According a survey by comptroller general of India, over $75 \%$ of Indian youths from 15 to 35 yrs of age are non vegetarians. There is a great variation between the demand and supply of Indian poultry population dynamics. Indian poultry industry is captured more than $90 \%$ by corporate sector and very less by unorganized farming. Hence, there is a lot of scope for improvement and catching the flow of poultry market. In this assignment we will be focusing on detailed aspects of poultry production in India. Poultry products have become more common in non- vegetarians (Adbhai et al., 2019).

Supplementation of Cardamom is increasing in many feed items due to its medicinal use and by virtue of its pleasant flavor. Studies on Supplementation of Cardamom suggest that Teucrium polium has different active compounds, such as flavonoids, tannins, saponin, glycosides, terpenes and steroids (Cazzola et al., 2011). It has been investigated that Cardamom is enriched with antioxidant, anti-inflammatory, digestive, appetite stimulant, carminative properties and in addition to it, Cardamom has beneficial impact when it is utilized as feed additive in the diet of poultry (Arshad et al,. 2010). Cardamom has been known as the "Queen of all spices". Cardamom has antibacterial properties similar to that of probiotics for gram negative bacterium (Martha et al., 2012). Elaichi (cardamom) is a good aromatic, digestive stimulant and carminative. The above mentioned beneficial properties in Cardamom are due to the presence of specific oils in it. Elaichi (cardamom) supplementation in food has shown increase in blood circulation, reduced toxin level in the blood and increases elimination of these toxins by inducing mild diuresis. It also has anti-allergic effects which may be useful against allergic skin rashes and urticaria.

Ginger (Zingiber officinale) is a medicinal herb used on a large scale as a spice, for pickles, candies, and preservatives. This plant belongs to the family Zingiberacy; which are aromatic herbs having fleshy, tuberous or nontuberous rhizomes and, often have tuber bearing root (Mohamed et al., 2012). The major components of ginger are zingiberene and gingerol which has the ability to stimulate the digestive system thereby influencing the digestive $\mathrm{pH}$ and the functioning of digestive enzyme including microbial activity.

Ginger (Zingiber officinale) rhizome is widely used as spice or condiment (Martha et al., 2012) and medical treatment for certain diseases (Ademola et al., 2009; Herawati, 2010; Sadeghi et al., 2013). Ginger contains several compounds such as gingerol, gingerdiol, and gingerdione that possess strong antioxidant activity (Ademola et al., 2009). The use of ginger as substitute for antibiotic growth promoter is desirable for greater productivity of poultry, increased palatability of feed, nutrient utilization, appetite stimulation, increase in the flow of gastric juice and piquancy to tasteless food (Onu, 2010).

The rhizome of Zingiber officinale Roscoe (Zingiberiaceae), commonly known as ginger is one of the essential kitchen spices possessing a list of many health benefits. Ginger is also used as one of the home remedies in treating various gastric problems like constipation, dyspepsia, belching, bloating, gastric, discomfort, ulcerations, and indigestion to both human and animals.

This study was framed to study the effects of supplementation of Cardamom and Ginger powder and their combination on feed intake 
and body weight on week basis in caged broilers.

\section{Materials and Methods}

The present experiment entitled "Effect of Cardamom and Ginger Powder Supplementation on Growth Performance and Feed Efficiency in Caged Broilers" was carried out in small animal laboratory of Department of Animal Husbandry \& Dairying SHUATS, Prayagraj, India.

\section{Distribution of Broilers}

The experiment commenced on $18^{\text {th }}$ April 2019 and continued till $22^{\text {nd }}$ May 2019 for the period of five weeks. A total no. of 48 day-old broiler chicks (DOC) of same hatch were procured. The chicks were weighed, leg banded and distributed randomly into four groups with four sub groups comprising of three chicks. Statistically similar body weight chicks were taken for this experimentation as shown in Table 1. Chicks were fed starter ration up to 3 weeks age (1 to 21 days) and then broiler finisher ration up to 3-5 weeks age (22-35 days) as per following dietary regimes:

\section{Details of dietary treatments}

The experimental birds were subjected to the following dietary treatments

\section{Details of dietary treatments:}

$\mathrm{T}_{0}$ (control) Standard ration as per NRC

$\mathrm{T}_{1}$ Ration supplemented with $0.5 \mathrm{~g}$ Cardamom powder $/ \mathrm{kg}$ feed

$\mathrm{T}_{2}$ Ration supplemented with $0.5 \mathrm{~g}$ Ginger powder $/ \mathrm{kg}$ feed

$\mathrm{T}_{3}$ Ration supplemented with 0.25 Cardamom +0.25 Ginger powder $/ \mathrm{kg}$ feed
The birds were reared in battery type cages under standard manage mental practices from day-old to five weeks of age. Cardamom and Ginger was supplemented as per dietary regimes of treatments. Broiler starter ration containing CP: 22 per cent and, ME:2900 k.cal./kg. Feed was fed up to three weeks of age and broiler finisher ration containing $\mathrm{CP}$ : 19 percent and ME: $3000 \mathrm{k} . \mathrm{cal} . / \mathrm{kg}$. fed up to five weeks as shown in table 2. The ration was fed ad-libitum to the birds. Initial weight of each chick was recorded on arrival and then weekly to obtain the growth rate. The feed consumption was also recorded weekly to determine the feed conversion ratio. The mortality rate was Nil.

\section{Housing and management}

Before arrival of broilers chicks, the experimental pens, waterers, feeders and floor were cleaned, washed, disinfected and fumigated by using formaldehyde and potassium permanganate. The experimental birds were reared under caged system. The experimental birds were reared under caged system. The uniform standard management practices were followed for all the groups throughout the experimental period. The cage system was supplied with electric bulb in each chamber as a source of heat and light and also temperature was maintained in broiler shed.

\section{Feeding and watering}

Grinded maize was provided for the first day and thereafter, the feed was offered in chick feeders and then in grower feeders throughout the experiment. The ad-lib feeding and ample of clean drinking water was made available during the experiment. Weighed amount of feed was offered to all the treatments and groups and the left over feed was collected and weighed separately at the end of the week. From this data, the average weekly feed consumption was calculated. 


\section{Feed consumption}

The daily feed consumption of each group was estimated as differences between the total quantity of feed offered and quantity of feed left over during 24 hours period. Feed consumption so recorded was added together for seven days of the week and was considered as weekly feed consumption.

\section{Live weight gain}

The growth rate of the birds is reflected through the weekly live weight gain. Individual body weight of the birds from each group was taken at weekly interval, starting from the day old stage. The birds were weighted during morning hours before feeding. The average weekly weight gain of the birds of the different groups was calculated by subtracting the previous week average weight of the group of the birds from the present weekly average weight of the group of birds.

\section{Feed conversion ratio}

The amount of feed consumed per unit gain (feed conversion ratio) was calculated as the ratio of feed consumed to weight gain during the experimental period feed consumption and weight gain for each week worked out for each treatment separately.

Feed conversion ratio $=$

Quantity of feed Intake / Gain in body weight

\section{Statistical analysis}

The data on various parameters were recorded, tabulated and statistically (Table 3) analyzed using analysis of variance (ANOVA) technique as per Snedecar \& Cocharan (1994).

\section{Critical differences}

The critical difference was calculated with the help of following formula:

$\mathrm{CD}=\frac{\sqrt{2 M S S(E)}}{r} \times t$ error

Where,

SE - Standard error

$\mathrm{CD}$ - Critical differences

$r$ - No. of replication

t error - Treatment error

\section{Results and Discussion}

Weekly average gain in weight (g) of broilers

The data regarding average feed intake of broilers randomly distributed into control $\left(\mathrm{T}_{0}\right)$ three different treatments $\left(\mathrm{T}_{1}, \mathrm{~T}_{2}, \mathrm{~T}_{3}\right)$ are presented in Table 4.

In general, average gain in weight of broilers at first, second, third, fourth, and fifth weeks of age ranged from $104.66 \mathrm{~g}$ to $124.33,261.33$ to $333.00,223.04$ to $359.67,436.31$ to 642.68 , $89.67-325.67 \mathrm{~g}$. At first week of age the average highest gain in weight in body of broilers was recorded in $\mathrm{T}_{3}(123.09)$ followed by $\mathrm{T}_{1}$ (1121.59), $\mathrm{T}_{2}$ (119.92), $\mathrm{T}_{0}$ (114.00). At second week of age the average gain in weight body of broilers was recorded in $\mathrm{T}_{3}$ (313.83) followed by $\mathrm{T}_{1}$ (303.08), $\mathrm{T}_{0}$ (295.34), $\mathrm{T}_{2}$ (280.58). At third week of age the average highest gain in weight of broilers was recorded in $T_{2}$ (307.69) followed by $T_{1}$ (292.13), $\mathrm{T}_{3}$ (281.51), $\mathrm{T}_{0}$ (273.94). At fourth week of age the average highest gain in weight in body of broilers was recorded in $\mathrm{T}_{3}$ (606.91) followed by $\mathrm{T}_{1}$ (544.54), $\mathrm{T}_{0}$ (522.07), $\mathrm{T}_{2}$ (517.48). At fifth week of age the average highest weight gain in body of broilers was recorded in $\mathrm{T}_{0}$ (223.25) followed 
by $\mathrm{T}_{2}$ (221.92), $\mathrm{T}_{1}$ (169.00), $\mathrm{T}_{3}$ (129.25) Irrespective of week, the mean average gain in weight per broilers at first, second, third, fourth and fifth week was $119.65,298.20$, $288.81,547.75$, and $185.85 \mathrm{~g}$, respectively.

Irrespective of treatment, mean average gain in weight per broiler in $\mathrm{T}_{0}, \mathrm{~T}_{1}, \mathrm{~T}_{2}$ and $\mathrm{T}_{3}$ was $119.65,298.21,288.81,547.75$, and $185.86 \mathrm{~g}$ respectively. From the perusal of data on weekly average gain in weight per broilers after five week of age contained in Table 4 and Figure 1. It may be noted that mean gain in weight per broilers, irrespective of weekly at one, two, three, four and five week of age was $119.65,298.20,288.81,547.75$, and $185.85 \mathrm{~g}$ respectively. When treatment wise gain in weight of broilers was recorded the highly weekly gain in weight was observed in $\mathrm{T}_{3}$ (547.75), $\mathrm{T}_{1}$ (298.20), $\mathrm{T}_{2}$ (288.81) However the differences in these values of treatment were found to be significant.

Table.1 Average Body weight ( $\mathrm{g}$ ) of day old chicks in different treatments

\begin{tabular}{|c|c|c|c|c|c|}
\hline \multirow{2}{*}{ Replication } & \multicolumn{5}{|c|}{ Body weight of DOC (g) } \\
\cline { 2 - 6 } & T0 & T1 & T2 & T3 & Mean \\
\hline R1 & 47.33 & 48.66 & 48.66 & 48.66 & $48.33^{\mathbf{a}}$ \\
\hline R2 & 47.33 & 48.66 & 50.00 & 44.00 & $47.50^{\mathbf{a}}$ \\
\hline R3 & 50.00 & 49.33 & 44.00 & 49.33 & $48.17^{\mathbf{a}}$ \\
\hline R4 & 47.33 & 48.66 & 45.33 & 50.33 & $47.91^{\mathbf{a}}$ \\
\hline Mean & $48.00^{\mathrm{a}}$ & $48.83^{\mathrm{a}}$ & $47.00^{\mathrm{a}}$ & $48.08^{\mathrm{a}}$ & \\
\hline
\end{tabular}

Means bearing similar superscripts are similar $(\mathrm{p}>0.05)$ under different rows and columns

Table.2 Ingredient and nutrient composition of experimental diet (\%DM)

\begin{tabular}{|l|c|c|}
\hline Ingredients (\%) & $\begin{array}{c}\text { Broiler Starter } \\
(\mathbf{0}-\mathbf{2 1} \text { day })\end{array}$ & $\begin{array}{c}\text { Broiler Finisher } \\
(\mathbf{2 2}-\mathbf{4 2} \text { days })\end{array}$ \\
\hline Corn & 60.00 & $\mathbf{6 3 . 0 0}$ \\
\hline Ground nut cake & 23.35 & $\mathbf{1 8 . 0 0}$ \\
\hline Fish meal & 13.00 & $\mathbf{1 5 . 0 0}$ \\
\hline Mineral mixture & 3.00 & $\mathbf{3 . 0 0}$ \\
\hline Common salt & 0.50 & $\mathbf{0 . 3 8}$ \\
\hline Vitamine Premix (vit. A, B, $\mathbf{D}_{\mathbf{3}}$ & 0.05 & $\mathbf{0 . 0 2}$ \\
\hline Amprosol & 0.05 & $\mathbf{0 . 0 5}$ \\
\hline Nuvimin & 0.05 & $\mathbf{0 . 5 5}$ \\
\hline Calculated Nutrient composition & & \\
\hline Moisture (\%) & 6.29 & $\mathbf{6 . 2 2}$ \\
\hline Crude protein (\%) & 22 & $\mathbf{1 9}$ \\
\hline Total ash (\%) & 8.02 & $\mathbf{9 . 3 4}$ \\
\hline Crude fiber & 5.5 & $\mathbf{6 . 0 0}$ \\
\hline ME (Kcal/kg) & $\mathbf{2 9 0 0}$ & $\mathbf{3 0 0 0}$ \\
\hline
\end{tabular}


Table.3 Structure of analysis of variance (ANOVA)

\begin{tabular}{|c|c|c|c|c|c|c|c|c|c|}
\hline \multicolumn{3}{|c|}{ Sources of variation } & d. $f$ & S.S & M.S.S & F. cal & F. table & Result & CD \\
\hline \multicolumn{3}{|c|}{ Treatment } & $\mathrm{t}-1$ & $\mathrm{SS}(\mathrm{t})$ & $\operatorname{MSS}(\mathrm{t})$ & R1 & & $\mathrm{S} / \mathrm{NS}$ & \\
\hline \multicolumn{3}{|c|}{ Replication } & $\mathrm{r}-1$ & $\mathrm{SS}(\mathrm{t})$ & $\operatorname{MSS}(r)$ & $\mathrm{R} 2$ & & & \\
\hline \multicolumn{3}{|l|}{ Error } & $(\mathrm{r}-1)(\mathrm{t}-1)$ & ESS & MESS & & & & \\
\hline \multicolumn{3}{|l|}{ Total } & Rt-1 & & & & & & \\
\hline d. $f$ & - & \multicolumn{8}{|c|}{ degree of freedom } \\
\hline SS & - & \multicolumn{8}{|c|}{ sum square } \\
\hline MSS & - & \multicolumn{8}{|c|}{ Mean sum square } \\
\hline r 1 & - & \multicolumn{8}{|c|}{ MTSS/MESS } \\
\hline r 2 & - & \multicolumn{8}{|c|}{ MRSS/MESS } \\
\hline C.D & . & \multicolumn{8}{|c|}{ Critical differences } \\
\hline$S$ & - & \multicolumn{8}{|c|}{ Significant } \\
\hline NS & 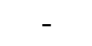 & \multicolumn{8}{|c|}{ Non-significant } \\
\hline $\mathrm{t}$ & - & \multicolumn{8}{|c|}{ Treatment } \\
\hline ANOVA & - & \multicolumn{8}{|c|}{ Analysis of variance } \\
\hline
\end{tabular}

Table.4 Average weekly means gain in weight of broiler chicks (g) of different treatments

\begin{tabular}{|c|c|c|c|c|c|c|}
\hline Treatments & W1 & W2 & W3 & W4 & W5 & Mean \\
\hline T0 & 114.00 & 295.34 & 273.94 & 522.07 & 223.25 & $285.72^{\mathrm{a}}$ \\
\hline T1 & 121.59 & 303.08 & 292.13 & 544.54 & 169.00 & $286.07^{\mathrm{b}}$ \\
\hline T2 & 119.92 & 280.58 & 307.69 & 517.48 & 221.92 & $289.52^{\mathrm{c}}$ \\
\hline T3 & 123.09 & 313.83 & 281.51 & 606.91 & 129.25 & $290.92^{\mathrm{d}}$ \\
\hline Mean & $119.65^{\mathrm{A}}$ & $298.21^{\mathrm{D}}$ & $288.81^{\mathrm{C}}$ & $547.75^{\mathrm{E}}$ & $185.86^{\mathrm{B}}$ & \\
\hline
\end{tabular}

Means bearing different superscripts differ significantly $(\mathrm{p}<0.05)$ under different rows for treatment and columns in weekly means

Table.5 Average weekly means (FCR) or feed efficiency per broiler different treatments

\begin{tabular}{|c|c|c|c|c|c|c|}
\hline Treatments & W1 & W2 & W3 & W4 & W5 & Mean \\
\hline T0 & 1.23 & 1.83 & 1.56 & 1.29 & 2.34 & $1.65^{\mathrm{A}}$ \\
\hline T1 & 1.24 & 1.86 & 1.51 & 1.03 & 2.37 & $1.60^{\mathrm{A}}$ \\
\hline T2 & 1.32 & 1.94 & 1.46 & 1.30 & 2.33 & $1.67^{\mathrm{A}}$ \\
\hline T3 & 1.23 & 1.74 & 1.37 & 1.41 & 2.70 & $1.69^{\mathrm{A}}$ \\
\hline Mean & $1.26^{\mathrm{a}}$ & $1.84^{\mathrm{c}}$ & $1.48^{\mathrm{b}}$ & $1.26^{\mathrm{a}}$ & $2.43^{\mathrm{d}}$ & \\
\hline
\end{tabular}

Means bearing different superscripts differ significantly $(\mathrm{p}<0.05)$ under different column and rows respectively 
Fig.1 Average weekly gain in weight of caged broiler on diet supplemented with different cardamom and ginger powder

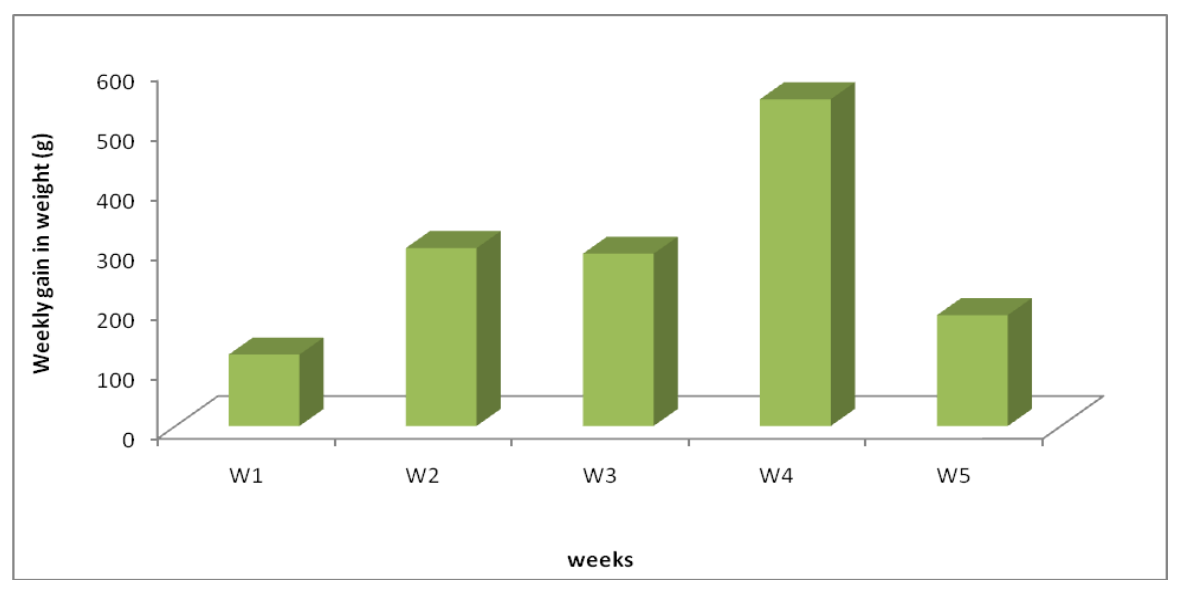

Fig.2 Average weekly feed conversion ratio of caged broilers on diet supplemented with different cardamom and ginger powder

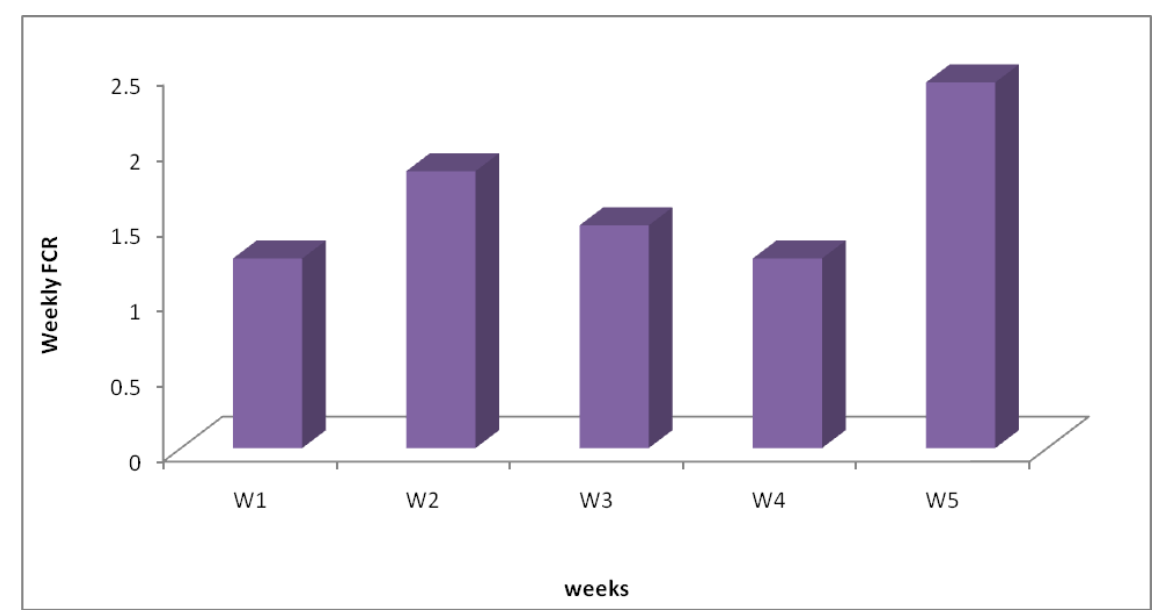

It has been pertinent by Figure 1 that major body weight gain has been seen in $4^{\text {th }}$ week as compared to other weeks. The effect of treatment was seen significant $(\mathrm{p}<0.05)$ as shown in Table 4. This can be stated from here that this increased body weight gain may be due to positive effect of supplementation of caged broilers with Cardamom and Ginger. Patel and Srinivasan, (2000) studied that Ginger has been suggested to improve pancreatic lipase activity of intestinal lipase, disaccharides, and sucrose and maltase activities of rats. It has been found to have favorable effects on gut function, which is suggested as the primary mode of action for growth promoting feed additives. Narahari and Ahmed (2003) investigated that significantly higher body weight and feed intake livability was achieved in treatment group broilers as compared to that of control group chicks. However due to better growth rate, $2.1 \%$ better feed efficiency was observed in treatment group chicks than control group in broiler from 0-6 week age. Biswas et al., (2005) found that body weight of eight week old chicks of same age was in range from $185.71+3.64 \mathrm{~g}$ to $191.43+3.84 \mathrm{~g}$ between different groups. Ao et al., (2011) expressed 
that garlic did not show significant affect on glucose level in blood of control group birds compared with the treatment group birds.

Average weekly FCR of broilers of different treatment (kg. feed per $\mathrm{kg}$. of weight)

The data regarding average feed conversion ratio (FCR) per broiler during first week of age randomly distributed into control $\left(\mathrm{T}_{0}\right)$ three different treatments $\left(\mathrm{T}_{1}, \mathrm{~T}_{2}, \mathrm{~T}_{3}\right)$ are presented in Table 5.

At first week of age the best FCR per broilers was recorded in $T_{2}(1.32)$ and followed by $T_{1}$ (1.24), $\mathrm{T}_{3}$ (1.23), $\mathrm{T}_{0}$ (1.23) kg. At second weeks of age the best FCR per broilers was recorded in $T_{2}$ (1.94) and followed by $T_{1}$ 1.86), $\mathrm{T}_{0}(1.83), \mathrm{T}_{3}(1.74) \mathrm{g}$. At third weeks of age the best FCR per broilers was recorded in $\mathrm{T}_{0}$ (1.56) and followed by $\mathrm{T}_{1}(1.51), \mathrm{T}_{2}$ (1.46), $\mathrm{T}_{3}(1.37) \mathrm{g}$. At fourth weeks of age the best FCR per broilers was recorded in $\mathrm{T}_{3}$ (1.41) and followed by $\mathrm{T}_{2}(1.30), \mathrm{T}_{0}(1.29), \mathrm{T}_{1}(1.03)$ g. At fifth weeks of age the best FCR per broilers was recorded in $\mathrm{T}_{3}$ (2.70) and followed by $\mathrm{T}_{1}$ (2.37), $\mathrm{T}_{0}$ (2.34), $\mathrm{T}_{3}$ (2.33). Irrespective of weekly the mean average FCR per broiler in first, second, third, fourth and fifth week of age was 1.26, 1.84, 1.48, 1.26, and $2.43 \mathrm{~g}$ respectively. Irrespective of treatment the mean FCR per broiler in $\mathrm{T}_{0}, \mathrm{~T}_{1}$, $\mathrm{T}_{2}$ and $\mathrm{T}_{3}$ was $1.65,1.60,1.67$ and $1.69 \mathrm{~g}$ respectively. From the perusal of data on weekly average feed conversion ratio per broiler contained in Table 5 and Figure 2. It may be observed that the mean average FCR per broilers, irrespective of weekly at one, two, three, four and five week of age was 1.26, 1.84, 1.48, 1.26, and $2.43 \mathrm{~kg}$ respectively. These results were expected. Regarding the influence of treatment on weekly FCR per broiler was observed that mean FCR of different treatments were1.65, 1.60, 1.67 and 1.69 However the differences in these values of treatment were found non significant.

Srivastava and Mustafa (1989) found that Ginger supplementation shown to be effective towards controlling the growth of both Gramnegative and Gram-positive bacteria including Escherichia coli, proteus vulgaris, Salmonella typhimurium, staphylococcus aureus and streptococcus viridans. The ingredients of Ginger improve liver functions thereby resulting in better utilization of several nutrients that ultimately adds up to the improved body weight and feed conversion. El-Deek et al., (2002) in an experiment observed that that diet containing $1 \mathrm{~g} / \mathrm{kg}$ of Ginger had a non- significantly affect on the growth performance in broilers under different groups. Al-Moramadhi (2010) investigated the effect of ginger root infusion on some physiological parameters in broiler. The results showed that there was no significant effect of Ginger root supplementation on body weight and food intake of broiler chicks among different groups. Elamin et al., (2011) studied the response of broiler chicks to dietary cardamom (Elettaria cardamomum) as a natural feed additive on broiler performance and blood parameter. Broiler diets were supplemented with four levels of cardamom $(0.0 \%, 0.15 \%, 0.30 \%$ and $0.45 \%)$. The treatment group had significantly $(\mathrm{p}>0.05)$ lower blood total lipid and glucose values. However, a non- significant ( $p>0.05)$ effect on blood total protein was observed. Amar et al., (2013) shown that the addition of Ginger essential oil to the diet led to non- significant effect on the feed intake, weight gain and feed conversion ratio in different broiler groups. Arshad et al., (2010) studied that the dietary addition of Ginger powder at different levels showed improved feed intake, weight gain and feed conversion in broiler chicks which were supplemented as compared to nonsupplemented group. 
In conclusions, this study supplementation of Cardamom and Ginger powder and their combination was provided to the caged chicks with an objective to study the effect of supplementation on weekly body weight gain and feed efficiency of caged broilers. The best results for body weight gain was seen for the group of caged chicks supplemented with combination of Cardamom and Ginger powder each @0.25 g/kg feed followed by individually supplementing chicks with Cardamom and Ginger powder than without supplemented group i.e. control group. However, feed efficiency was similar among different groups. Nevertheless, there was significant effect of weeks of cage rearing in the feed efficiency. Hence, from this study it can be concluded that supplementation of Cardamom and Ginger powder in combination form may be done to achieve improved body weight gain at finisher stage.

\section{Recommendation}

This study brings out the insights of using Cardamom and Ginger powder individually and in combination for caged broilers. However, it is recommended to carry similar study on supplementation of Cardamom and Ginger powder in combination on large number of chicks for further detailed study including hematological, internal organs, muscle quality for more knowledge on this type of study. Nevertheless, this study will be a basis of further study on supplementation of Cardamom and Ginger powder in combination.

\section{Acknowledgement}

Authors have deep regards towards Vice Chancellor and Head, Department of Animal Husbandry \& Dairying of SHUATS, Prayagraj for providing all the necessary facilities for conducting this experiment.

\section{Conflict of Interest}

Authors declare that they do not have any conflict of interests.

\section{References}

Adbhai, A.D., Singh, A.K., Bhand, D.S., Kumar, P., Ghorpade, S. and Patil, V. (2019). Alternative poultry production for rural livelihood: A review. Journal of Entomology and Zoology Studies, 7(5): 559-562.

Ademola, S., Farinu, G.O. and Babatunde, G.M. (2009). Serum lipid, growth and haematological parameters of broilers fed Garlic, Ginger and their mixtures. World Journal Agriculture Science, 5(1): 99104.

Al-Moramadhi, S. A. H. (2010). The effect of Zingiber officinali roots infusion on some physiological parameters in broiler chickens. Kufa Journal for Veterinary Medical Sciences, 1(2): 67-76.

Amar, A., Amar, M.J.S., Edgar, C. and Faisan, J.P. (2013). Growth, plasma cortisol, liver and kidney histology, and resistance to vibriosis in brown-marbled grouper, Epinephelus fuscoguttatus fed onion and ginger. Aquaculture, Aquarium, Conservation \& Legislation; ClujNapoca, 6(6): 530-538.

Ao, X., Yoo, J.S., Zhou, T.X., Wang, J.P., Meng, Q.W., Yan, L., Cho, J.H. and Kim, I. H. (2011). Effects of fermented garlic powder supplementation on growth performance, blood profiles and breast meat quality in broilers. Livestock Science, 141: 85-89.

Arshad M, Kakar A.H, Durrani F.R, Akhtar A, Shakirullah S, Niamatullah M. (2010). Economical and immunological impact of Ginger (Z. officinale) extract on broiler chicks. Pakistan Journal Science, 64: 4648.

BAHS (Basic Animal Husbandry Statistics). (2019). Department of Animal Husbandry, Dairying and Fisheries, Ministry of Agriculture, Government of 
India.April, 2012.http://www.dahd.nic.in.

Biswas, P.K., Biswas, D., Ahmed, S., Rahman, A. and Debnath, N. C. (2005). A longitudinal study of the incidence of major endemic and epidemic diseases affecting semiscavenging chickens reared under the Participatory Livestock Development Project areas in Bangladesh. Avian Pathology, 34: 303-312, DOI: 10.1080/03079450500178972.

Cazzola R, Camerotto C, Cestaro B (2011). Anti-oxidant, anti-glycant, and inhibitory activity against $\alpha$-amylase and $\alpha$ glucosidase of selected spices and culinary herbs. International Journal of Food Science and Nutrition, 62(2):175184.

Elamin, R.F., Khadiga, A., Abdel, A. and Bakheit, M.D. (2011). Response of broiler chicks to dietary cardamom (Elettaria cardamomum) as a feed additive. University of Khartoum Journal of Veterinary Medicine and Animal Production, 2: 33-48.

El-Deek, A.A., Attia, Y.A. and Hannfy, M.M. (2002). Effect of anise (Pimpinella anisum), ginger (Zingiber officinale roscoe) and fennel (Foeniculum vulgare) and their mixture on performance of broilers. Archiv fur Geflugelkunde, 67 (2): $92-96$.

Herawati, O. (2010). The effect of red ginger as phytobiotic on body weight gain, feed conversion and internal organs condition of broiler. International Journal of Poultry Science, 9: 963-967.

Martha, D.O., Adetokunbo, S.A., Olabanji, O.S., Takpejewho, E.G. and Sunday, O.T. (2012). The effect of supplementation of enzyme on performance and some blood chemistry parameters in broiler finisher chickens fed ginger byproduct meal (Zingiber officinale). International Journal of Biological Sciences, 2(7):5965.

Mohamed, A.B., Mohammed, A.M. and Ali Jalil, Q. (2012) Effect of ginger (Zingiber officinale) on performance and blood serum parameters of broiler. International Journal of Poultry Science, 11(2):143146.

Narahari, D. and Ahmed, M. (2003). Relative efficacy of herbal growth promoters on broiler performance. Poultry Fortune, 2003: 32-33.

Onu, P.N. (2010). Evaluation of two herbal spices as feed additives for broilers diet. Biotechnology in Animal Husbandry, 26 (5-6): 383-392.

Patel, K. and Srinivasan, K. (2000). Influence of dietary spices and their Active principles on pancreatic digestive enzymes in albino rats. Nahrung, 44: 42-46.

Sadeghi, A.A., Izadi, W., Shawrang, P., Chamani, M. and Afshar, M.A. (2013). A comparison of the effects of dietary ginger powder and Avilamycin on growth performance and intestinal Salmonella count of challenged broiler chickens. Iranian Journal Applied Animal Science, 3(4):769-775.

Snedecor, G.W. and Cochran, W.G. (1994). Statistical method. 8th edition. Oxford and IBG publication co., New Delhi, India.

Srivastava, K. C. and Mustafa, T. (1989). Ginger (Zingiber officinale) and rheumatic disorders. Medical hypotheses, 29(1): 25-28. https://doi.org/10.1016/03069877(89)90162-x.

\section{How to cite this article:}

Ramkumar Thakur, Neeraj, Ramesh Pandey, Amit Kumar Singh and Abhishek Nagar. 2020. Effect of Cardamom and Ginger Powder Supplementation on Body Weight Gain and Feed Efficiency in Caged Broilers. Int.J.Curr.Microbiol.App.Sci. 9(08): 2159-2168. doi: https://doi.org/10.20546/ijcmas.2020.908.246 